\title{
The Relation between Intravenous Fluid Intake and the Course of Labour in Primigravida
}

\author{
ABD EL-GHAFFAR M. AHMED, M.D.; SAFWAT A. MOHAMMED, M.D.; AHMED I. HASSANEIN, M.D. and \\ SHAIMA ALI, M.Sc.
}

The Department of Obstetrics \& Gynaecology, Faculty of Medicine, Women Health Hospital, Assiut University

\begin{abstract}
Objectives: To study the impact of maternal intravenous hydration on the following: Labor duration, the need for oxytocin administration, and the occurrence of adverse outcomes due to prolonged labor.
\end{abstract}

Patients and Methods: In a randomized clinical trial 120 nulliparous women with normal singleton pregnancies divided in to three groups. Group A: Included 40 pregnant women received $250 \mathrm{ml}$ per hour. Group B: Included 40 pregnant women received $125 \mathrm{ml}$ per hour. Group C: Included 40 pregnant women did not receive any IV fluids.

Results: The duration of uterine contractions and active labor we found that all these measures were significantly higher in the $250 \mathrm{ml}$ group $37.9 \pm 3.1$ than in the $125 \mathrm{ml}$ group and the control group. There was no significant difference in frequency of oxytocin administration for inadequate labor progress and mode of delivery between the three groups. There was no significant difference between the three groups according to neonatal wellbeing by apgar score at 1,5 and 10 minute after birth.

Conclusion: It has been found that adequately hydrated women had a shorter labor duration than poorly hydrated women and that they did not require oxytocin as frequently for labor augmentation.

Key Words: Labour-Hydration - Partogram-Intravenous fluid-Primigravida.

\section{Introduction}

LABOR has been described as uterine smooth muscle contractions resulting in progressive cervical dilation and effacement accompanied by the descent and expulsion of the fetus [1]. Factors affecting labor progression have been widely studied, including hydration [2]. Adequate maternal hydration is vital for fetal oxygenation, delivery of Nutrients, and removal of waste from the contracting myometrium during labor. It is, therefore,

Correspondence to: Dr. Abd El-Ghaffar M. Ahmed,

The Department of Obstetrics \& Gynaecology, Faculty of Medicine, Women Health Hospital, Assiut University likely that by placing women in danger of dehydration, restricting oral fluids during labor increases the rates of dysfunctional labor and cesarean delivery [1]. It has been reported that adequately hydrated women had a shorter labor duration than poorly hydrated women and that they did not require oxytocin as frequently for labor augmentation [3]. Maternal exhaustion and dehydration due to prolonged labor has been associated with a more frequent need for epidural analgesia and cesarean delivery, and also with a greater occurrence of maternal or fetal infection, adverse birth outcomes, and postpartum hemorrhage [4]. Factors that affect progress of labor have been studied extensively in an effort both to increase our understanding of normal labor and to improve our ability to treat abnormal labor so that labor progress can be enhanced and operative deliveries avoided [5]. The intravenous fluid administered to nulliparous women in active labor is associated with significantly shorter duration of labor and lower frequency of both prolonged labor and oxytocin administration [2]. The inadequate hydration in labor may be a factor contributing to dysfunctional labor and possibly cesarean delivery. Exercise physiologists have shown that adequate hydration improves muscle performance in prolonged exercise [6] Adequate fluid would be important for optimal uterine perfusion, required not only for fetal oxygenation but also for delivery of nutrients and elimination of waste from the contracting myometrium. In most labor units, oral liquid is restricted because of concern over aspiration if an unanticipated general anesthetic is required [2].

\section{Patients and Methods}

This is a randomized controlled trial that has been done at Obstetrics and Gynaecology Department at Women Health Hospital Assuit University to study the relation between hydration and labour. 
In our study we included 120 nulliparous pregnant women admitted to the hospital in active phase of labour. The study conducted between August 2014 to August 2015. After ethical approval. We included women that are nulliparous, having a singleton pregnancy with gestational age of 37 weeks or more. For women to be included in the study they should have spontaneous onset of labor and in active phase of labour with cervical dilatation from 4 to $5 \mathrm{~cm}$, cephalic presentation and intact membranes. Moreover, they should have normal antenatal care and not complaining of any medical or surgical disorder. All the regulations of the Ethical Committee of the faculty of the medicine were followed. Each patient had private file with non disclosure policy at data presentation where all presented data do not contain any personal information specifying the identity of any of the patients. All the patients had clear verbal description about the study. Women were divided into three groups:

- Group A: Included 40 pregnant women received $250 \mathrm{ml}$ per hour $=4 \mathrm{ml}$ per minute $(60-80 \mathrm{drops} /$ min) of IV fluid in the form of Ringer's solution.

- Group B: Included 40 pregnant women received $125 \mathrm{ml}$ per hour $=2 \mathrm{ml}$ per minute (30-40 drops/ $\mathrm{min}$ ) of Ringer's solution intravenously.

- Group C: Included 40 pregnant women did not receive any IV fluids.

N.B: We used intravenous infusion set and intravenous cannula with injection valve size $20 \mathrm{G}$, $1 \mathrm{ml}=15-20$ drops [7]. Sample size: In a study of three independent groups, the significance of the differences in three sample means is being evaluated using F-test (ANOVA). The alpha level is $\mathrm{a}=0.05$, effect size $\mathrm{f}=0.34$ and the power is 0.90 . Using GPower, for the total sample sizes, this was calculated for 'F-test' in GPower. Thus, 114 subjects would be needed in three groups.

Effect size conventions: Small 0.01, medium= 0.25 and large $=0.40$ :

Select

Type of power analysis

- Input:

Effect size f: 0.34 .

a err probability: 0.05 .

Power (1-b err probability): 0.90 .

Number of groups: 3 .

- Output:

Critical F: 3.1.

Numerator df: 2.

Total sample size: 114 .

Actual Power: 0.90.
About one hundred and twenty nulliparous women in active labor were included in this study divided in three groups. Out come measures: After counseling and consent, detailed form will be fulfilled. This form includes detailed obstetric history of current pregnancy, demographic pattern and the patient will be blotted on partograph. Strict observation and follow-up of the progress of labor and the fetus will be done, any deviation regarding failure of progress, fetal distress, maternal distress or vaginal bleeding; mother will be offered the opportunity to do ceasarian section. Initially all participating women will undergo the following: Full history taking to verify the critera for inclusion or exclusion including personal data: Included woman name, age, name of spouse, address, educational level. Obstetric data: Included last menstrual day, gestational age in weeks at time of admission, expected delivery date, obstetric history, parity. Current pregnancy data: Included any risk factors associated with this current pregnancy, bleeding during pregnancy, the separation of the placenta, intrauterine growth retardation, high blood sugar during the current pregnancy if blood sugar was $>140 \mathrm{mg} / \mathrm{dl}$, high blood pressure during pregnancy $>140 / 90 \mathrm{mmHg}$. Past history of any uterine surgery. Full examination was done for each women and must stress on estimated fetal weight, abdominal scars, fetal heart sounds and scar tenderness. Vaginal examination was done for each women and must stress on cervical dilation, cervical effacement, presenting part, head station, membrane integrity, position and pelvic adequacy. Investigation performed: Complete blood picture, urine analysis for albumin, sugar and ketones, Rhesus factor, random blood sugar. Ultrasonography: For singleton pregnancy, fetal viability, lie, presentation, gestational age, liqor amount, placental site, estimated fetal weight. 1 st stage of labor: Patient were observed for: Admission delivery time was recorded, progress of labor assessed every 2 hours, women with satisfactory progress (dilatation rate of $1 \mathrm{~cm} /$ hour or faster), women with failure of satisfactory progress (cervical dilatation rate of less than $1 \mathrm{~cm} /$ hour between any of these examinations). These women were managed by: The membranes were ruptured if still intact with a Kocher clamp. The labor was augmented by oxytocin (syntocinon) (Novartis), oxytocin 2.5 units in $500 \mathrm{ml}$ Ringer's lactate at 10 drops per minute $(2.5 \mathrm{mIU}$ per minute), and increasing the infusion rate by 10 drops per minute every 30 minutes until a good contraction pattern was established (contractions lasting more than 40 seconds and occurring three times in 10 minutes), maintaining this rate until delivery was completed. If uterine contractions 
were not satisfactory with the infusion rate at 60 drops per minute, the oxytocin concentration was increased to 5 units in $500 \mathrm{ml}$ Ringer's lactate and the infusion rate was adjusted to 30 drops per minute ( $15 \mathrm{mIU}$ per minute), increasing the infusion rate by 10 drops per minute every 30 minutes until a satisfactory contraction pattern was established or the maximum rate of 60 drops per minute was reached. If labor still has not been established using the higher concentration of oxytocin, we used oxytocin 10 units in 500ml Ringer's lactate at 30 drops per minute, increasing infusion rate by 10 drops per minute every 30 minutes until good contractions were established. If good contractions were not established at 60 drops per minute $(60 \mathrm{mIU}$ per minute), delivery was achieved by caesarean section. Continuous electronic fetal monitoring intrapartum complications. 2 nd and 3 rd stage of labor: Either delivered by vaginal delivery or cesarean section. 4 th stage of labor the following were done, vaginal examination, observation for any postpartum complications, the need for blood transfusion and fetal outcome, (fetal weight, Apgar score).

Apgar score is a clinical assessment of neonatal wellbeing, it is performed at 1 and 5 minutes after birth and repeated every five minute if score is low, it is based on five clinical signs: Heart rate, respiratory effort, reflex irritability, muscle tone and colour. Each of these items is rated with the three response options: 0, 1 and 2 and all are added to comprise the Apgar score which can range from 0 to 10 . A score of 7-10 is considered to be normal condition, 4-6 (mild asphyxia), 0-3 (sever asphyxia). Comparison of fetal and maternal outcome in the three groups. And partogram was done to observe the following: The condition of the mother, the condition of the fetus, and the progress of labor were recorded on the partogram.

\section{Statistical analysis: The following tests were used:}

Descriptive analysis of the results in the form of percentage distribution for qualitative data (minimum, maximum, mean and standard deviation) calculation for quantitative data. Cross tabulation test: For comparison between percentage values. Paired samples $t$-test: A paired sample $t$ test is used to determine whether there is a significant difference between the average values of the same measurement made under two different conditions. F-Test (One way ANOVA): A test statistics calculated for comparison between means of three groups. Kruskal-Wallis test for several independent samples. The Kruskal-Wallis test is a nonparametric test that is used with an independent groups design comprising of more than two groups. $p$ : The prob- ability/significance value. $p$-value $>0.05$ (NS) Not Significant. $p$-value $<0.05 *$ Significant at 0.05 level, $p$-value $<0.01 * *$ Significant at 0.01 level. For statistical analysis, Statistical Package for Social Science (SPSS) software Version 17 was used.

\section{Results}

There were one hundred twenty pregnant women in active phase participated in this study, patients were admitted to the labour of the Obstetrics and Gynaecology Women Health Hospital Assuit University Women were randomly divided into three groups according to rate of intravenous Ringer's solution which was given to them, each group included 40 women. Group A: Received 250ml per hour, group B: Received $125 \mathrm{ml}$ per hour and group C: (Control group) received no intravenous fluid.

There was no statistically significant difference between the three groups as regards maternal age, number of contractions per 10 minutes, duration of contractions in seconds and station of the head, at the start of the active of phase.

As presented in Table (1), when comparing the three groups for the progress of labor by measuring the duration of uterine contractions and active labor we found that all these measures were significantly higher in the $250 \mathrm{ml}$ group than in the $125 \mathrm{ml}$ group and the control group.

Table (1): Comparison between group A, group B and group $\mathrm{C}$ as regarding duration of contraction and duration of active phase.

\begin{tabular}{|c|c|c|c|c|c|}
\hline & $\begin{array}{c}\text { Group A } \\
\text { Mean } \pm \text { SD }\end{array}$ & $\begin{array}{c}\text { Group B } \\
\text { Mean } \pm \text { SD }\end{array}$ & $\begin{array}{c}\text { Group C } \\
\text { Mean } \pm \text { SD }\end{array}$ & $\begin{array}{c}p- \\
\text { value }\end{array}$ & Sig. \\
\hline $\begin{array}{l}\text { Duration of } \\
\text { contraction } \\
\text { in seconds } \\
\text { (After } 2 \\
\text { hour) }\end{array}$ & $37.9 \pm 3.1$ & $36.4 \pm 2.0$ & $35.3 \pm 1.6$ & $\begin{array}{l}p=0.054 \\
p 1=0.065 \\
p 2=0.051 \\
p 3=0.050\end{array}$ & $\begin{array}{l}\mathrm{NS} \\
\mathrm{NS} \\
\mathrm{NS} \\
\mathrm{NS}\end{array}$ \\
\hline $\begin{array}{l}\text { - Duration of } \\
\text { contraction } \\
\text { (After } 4 \\
\text { hour) }\end{array}$ & $52.3 \pm 2.9$ & $44.2 \pm 5.2$ & $40.7 \pm 1.6$ & $\begin{array}{l}p=0.001 \\
p 1=0.001 \\
p 2=0.001 \\
p 3=0.001\end{array}$ & $\begin{array}{l}\text { HS } \\
\text { HS } \\
\text { HS } \\
\text { HS }\end{array}$ \\
\hline $\begin{array}{l}\text { - Duration of } \\
\text { contraction } \\
\text { (After } 6 \\
\text { hour) }\end{array}$ & $57.4 \pm 2.8$ & $51.4 \pm 4.9$ & $47.4 \pm 3.8$ & $\begin{array}{l}p=0.001 \\
p 1=0.001 \\
p 2=0.001 \\
p 3=0.002\end{array}$ & $\begin{array}{l}\text { HS } \\
\text { HS } \\
\text { HS } \\
\text { HS }\end{array}$ \\
\hline $\begin{array}{l}\text { - Duration of } \\
\text { active } \\
\text { phase in } \\
\text { minutes }\end{array}$ & $296.1 \pm 60.8$ & $315.0 \pm 59.9$ & $344.0 \pm 68.4$ & $\begin{array}{l}p=0.004 \\
p 1=0.184 \\
p 2=0.001 \\
p 3=0.042\end{array}$ & $\begin{array}{l}\text { HS } \\
\text { NS } \\
\text { HS } \\
\text { S }\end{array}$ \\
\hline $\begin{array}{ll}p & : \mathrm{C} \\
p_{1} & : \mathrm{C} \\
p_{2} & : \mathrm{C} \\
p_{3} & : \mathrm{C} \\
\mathrm{S} \text { or } * & : p \\
\mathrm{HS} \text { or } * * & : p \\
p \text {-value } & >0.0\end{array}$ & $\begin{array}{l}\text { mparison bet } \\
\text { mparison bet } \\
\text { mparison bet } \\
\text { value }<0.05\end{array}$ & $\begin{array}{l}\text { ween group } \\
\text { tween group } \\
\text { Significant). } \\
\text { High signific }\end{array}$ & $\begin{array}{l}\text { ups. } \\
\mathrm{A} \text { and group } \mathrm{B} \\
\mathrm{A} \text { and group } \\
\mathrm{B} \text { and group } \\
\text { ant). }\end{array}$ & & \\
\hline
\end{tabular}


As shown in Table (2) there was no significant difference in frequency of oxytocin administration for inadequate labor progress and mode of delivery between the three groups.

Table (2): Comparison between group A, group B and group $\mathrm{C}$ as regarding frequency of oxytocin administration for inadequate labor progress and mode of delivery between studied groups.

\begin{tabular}{|c|c|c|c|c|}
\hline & $\begin{array}{c}\text { Group A } \\
(250 \mathrm{ml}) \\
(\mathrm{n}=40)\end{array}$ & $\begin{array}{c}\text { Group B } \\
(125 \mathrm{ml}) \\
(\mathrm{n}=40)\end{array}$ & $\begin{array}{c}\text { Group C } \\
\text { Control } \\
(n=40)\end{array}$ & $p$ \\
\hline $\begin{array}{l}\text { - Frequency of oxytocin } \\
\text { administration n. }(\%) \text {. }\end{array}$ & $9(22.5)$ & $12(30)$ & $16(40)$ & 0.235 \\
\hline - Mode of delivery n. (\%): & & & & \\
\hline - Normal delivery & $38(95)$ & $37(92.5)$ & $35(87.5)$ & 0.466 \\
\hline - Cesarean section & $2(5)$ & $3 \quad(7.5)$ & $5 \quad(12.5)$ & \\
\hline
\end{tabular}

As shown in Table (3) there was no significant difference between the three groups according to neonatal wellbeing by apgar score at 1,5 and 10 minute after birth.

Table (3): Comparison of neonatal wellbeing by Apgar score at 1,5 and 10 minute after birth.

\begin{tabular}{|c|c|c|c|c|}
\hline & $\begin{array}{c}\text { Group A } \\
(250 \mathrm{ml}) \\
(\mathrm{n}=40)\end{array}$ & $\begin{array}{c}\text { Group B } \\
(125 \mathrm{ml}) \\
(\mathrm{n}=40)\end{array}$ & $\begin{array}{c}\text { Group C } \\
\text { Control } \\
(n=40)\end{array}$ & $p$ \\
\hline \multicolumn{5}{|c|}{ Apgar score at 1 minute } \\
\hline \multicolumn{5}{|c|}{ after birth: } \\
\hline $7-10$ & $40(100)$ & $38(95)$ & $39(97.5)$ & 0.358 \\
\hline $4-6$ & $0 \quad(0)$ & $2(5)$ & $1 \quad(2.5)$ & \\
\hline $0-3$ & $0 \quad(0)$ & $0 \quad(0)$ & $0 \quad(0)$ & \\
\hline \multirow{2}{*}{\multicolumn{5}{|c|}{$\begin{array}{l}\text { Apgar score at } 5 \text { minute } \\
\text { after birth: }\end{array}$}} \\
\hline & & & & \\
\hline $7-10$ & $40(100)$ & $40(100)$ & $40(100)$ & 1 \\
\hline $4-6$ & $0 \quad(0)$ & $0 \quad(0)$ & $0 \quad(0)$ & \\
\hline $0-3$ & $0 \quad(0)$ & $0 \quad(0)$ & $0 \quad(0)$ & \\
\hline \multicolumn{5}{|c|}{ Apgar score at 10 minute } \\
\hline \multicolumn{5}{|c|}{ after birth: } \\
\hline $7-10$ & $40(100)$ & $40(100)$ & $40(100)$ & 1 \\
\hline $4-6$ & $0 \quad(0)$ & $0 \quad(0)$ & $0 \quad(0)$ & \\
\hline $0-3$ & $0 \quad(0)$ & $0 \quad(0)$ & $0 \quad(0)$ & \\
\hline
\end{tabular}

As shown in Table (4) frequency of uterine contractions were significantly higher in the $250 \mathrm{ml}$ group than in the $125 \mathrm{ml}$ group and the control group.

As shown in Table (5) and Figs. (1-3) descent of fetal head were significantly higher in the $250 \mathrm{ml}$ group than in the $125 \mathrm{ml}$ group and the control group.

As shown in Table (6) and Fig. (4) cervical dilation were significantly higher in the $250 \mathrm{ml}$ group than in the $125 \mathrm{ml}$ group and the control group.
Table (4): Comparison between group A, group B and group $\mathrm{C}$ as regarding frequency of uterine contraction (after 2, 4 and 6 hours).

\begin{tabular}{|c|c|c|c|c|c|c|}
\hline & $\begin{array}{l}\text { Number of } \\
\text { contraction }\end{array}$ & $\begin{array}{c}\text { Group A } \\
\text { No. }(\%)\end{array}$ & $\begin{array}{l}\text { Group B } \\
\text { No. (\%) }\end{array}$ & $\begin{array}{l}\text { Group C } \\
\text { No. }(\%)\end{array}$ & $\begin{array}{c}p- \\
\text { value }\end{array}$ & Sig. \\
\hline $\begin{array}{l}\text { - Uterine } \\
\text { contract } \\
\text { ion (after } \\
2 \text { hours) }\end{array}$ & $\begin{array}{l}2 \\
3\end{array}$ & $\begin{array}{l}22(55) \\
18(45)\end{array}$ & $\begin{array}{l}22(55) \\
18(45)\end{array}$ & $\begin{array}{l}34(85) \\
6(15)\end{array}$ & 0.005 & HS \\
\hline $\begin{array}{l}\text { - Uterine } \\
\text { contract } \\
\text { ion (after } \\
4 \text { hours) }\end{array}$ & $\begin{array}{l}3 \\
4\end{array}$ & $\begin{array}{l}24(66.7) \\
12(33.3)\end{array}$ & $\begin{array}{l}25(64.1) \\
14(35.9)\end{array}$ & $\begin{array}{l}34(85) \\
6(15)\end{array}$ & 0.079 & NS \\
\hline $\begin{array}{l}\text { - Uterine } \\
\text { contract } \\
\text { ion (after } \\
6 \text { hours) }\end{array}$ & $\begin{array}{l}3 \\
4\end{array}$ & $\begin{array}{ll}2 & (12.5) \\
14 & (87.5)\end{array}$ & $\begin{array}{ll}5 & (25) \\
15 & (75)\end{array}$ & $\begin{array}{l}16(64) \\
9(36)\end{array}$ & 0.001 & HS \\
\hline
\end{tabular}

$\mathrm{S}$ or $*: p$-value $<0.05$ (Significant)

HS or $* *: p$-value $<0.01$ (High significant).

$p$-value $>0.05$ (Non significant).

Table (5): Comparison between group A, group B and group $\mathrm{C}$ as regarding descent of fetal head (after 2, 4 and 6 hours).

\begin{tabular}{|c|c|c|c|c|c|}
\hline & $\begin{array}{l}\text { Group A } \\
\text { No. }(\%)\end{array}$ & $\begin{array}{l}\text { Group B } \\
\text { No. (\%) }\end{array}$ & $\begin{array}{l}\text { Group C } \\
\text { No. }(\%)\end{array}$ & $\begin{array}{c}p- \\
\text { value }\end{array}$ & Sig. \\
\hline \multicolumn{6}{|c|}{$\begin{array}{l}\text { Descent of fetal head } \\
\text { (after } 2 \text { hours): }\end{array}$} \\
\hline-1 & $14(35)$ & $25(62.5)$ & $30(75)$ & 0.003 & HS \\
\hline 0 & $22(55)$ & $14(35)$ & $10(25)$ & & \\
\hline 1 & $4 \quad(10)$ & $1 \quad(2.5)$ & $\begin{array}{ll}0 & (0)\end{array}$ & & \\
\hline \multicolumn{6}{|c|}{$\begin{array}{l}\text { Descent of fetal head } \\
\text { (after } 4 \text { hours): }\end{array}$} \\
\hline 0 & $9 \quad(25)$ & $20(51.3)$ & $28(70)$ & 0.001 & HS \\
\hline+1 & $17(47.2)$ & $16(41)$ & $11(27.5)$ & & \\
\hline+2 & $10(27.8)$ & $3 \quad(7.7)$ & $1 \quad(2.5)$ & & \\
\hline \multicolumn{6}{|c|}{$\begin{array}{l}\text { Descent of fetal head } \\
\text { (after } 6 \text { hours): }\end{array}$} \\
\hline 0 & $\begin{array}{ll}0 & (0)\end{array}$ & $\begin{array}{ll}0 & (0)\end{array}$ & $4 \quad$ (16) & 0.001 & HS \\
\hline+1 & $4 \quad(25)$ & $15(75)$ & $19(76)$ & & \\
\hline+2 & $12(75)$ & $5 \quad(25)$ & $2(8)$ & & \\
\hline
\end{tabular}

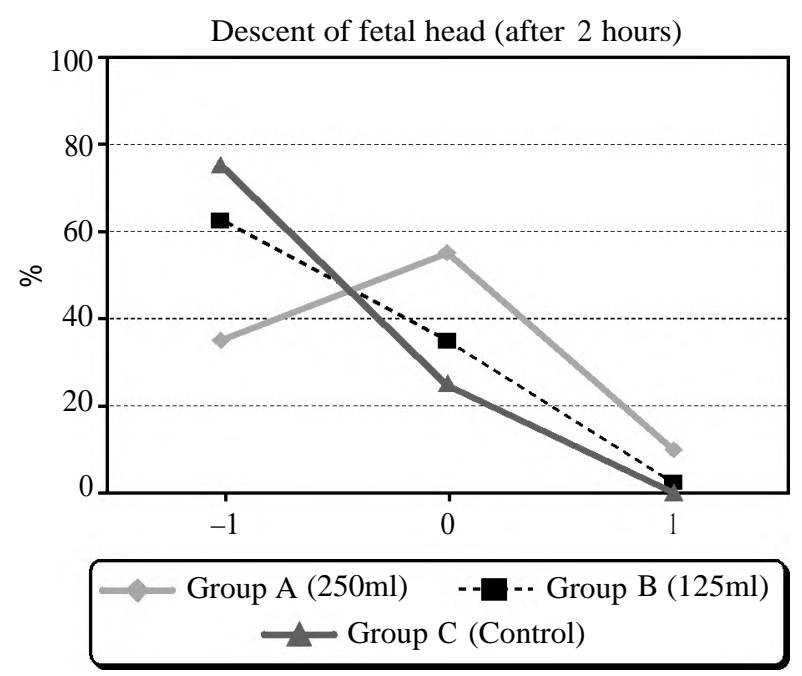

Fig. (1): Comparison between group A, group B and group C as regarding descent of fetal head (after 2 hours). 


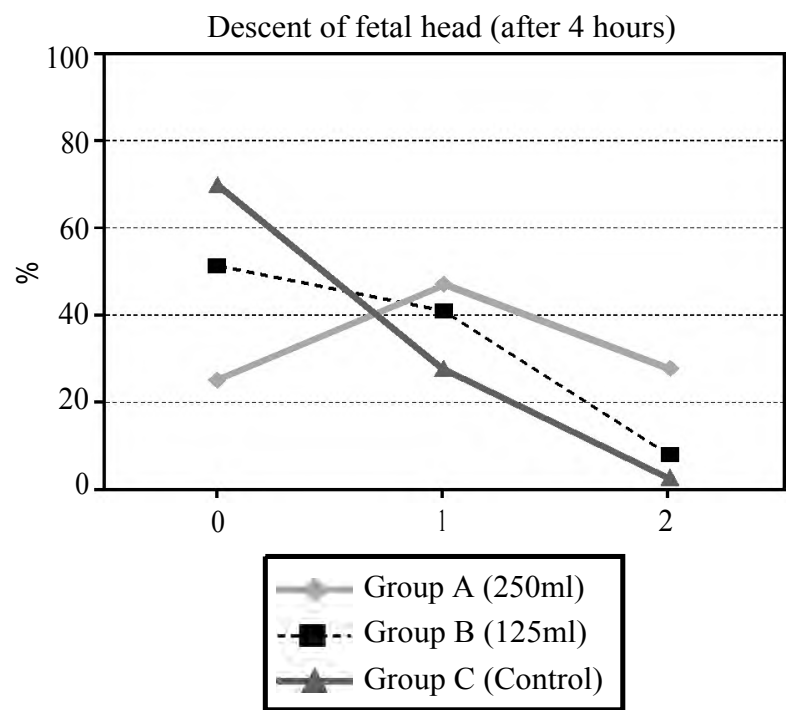

Fig. (2): Comparison between group A, group B and group C as regarding descent of fetal head (after 4 hours).

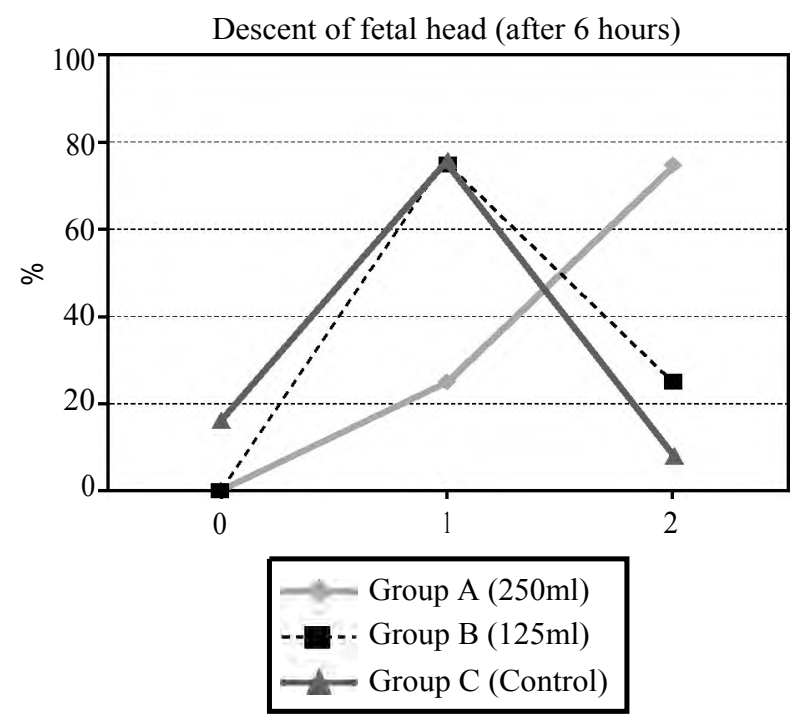

Fig. (3): Comparison between group A, group B and group C as regarding descent of fetal head (after 6 hours).

Table (6): Comparison between group A, group B and group $\mathrm{C}$ as regarding cervical dilation (after 2 hours).

$\begin{array}{lclllll} & \begin{array}{c}\text { Cervical } \\ \text { dilation } \\ (\mathrm{cm})\end{array} & \begin{array}{l}\text { Group A } \\ \text { No. (\%) }\end{array} & \begin{array}{l}\text { Group B } \\ \text { No. (\%) }\end{array} & \begin{array}{l}\text { Group C } \\ \text { No. (\%) }\end{array} & \begin{array}{c}p- \\ \text { value }\end{array} & \text { Sig } \\ \text { - Cervical } & 4 & 0(0) & 0(0) & 8(20) & 0.001 & \text { HS } \\ \text { dilation } & 5 & 22(55) & 25(62.5) & 30(75) & & \\ \text { (After 2 } & 6 & 8(20) & 14(35) & 2(5) & & \\ \text { hours) } & 7 & 6(15) & 1(2.5) & 0(0) & & \\ & 8 & 4(10) & 0(0) & 0(0) & & \end{array}$

As shown in Tables (7-9) and Figs. (5-7) frequency and duration of uterine contraction were significantly higher in the $250 \mathrm{ml}$ group than in the $125 \mathrm{ml}$ group and the control group.

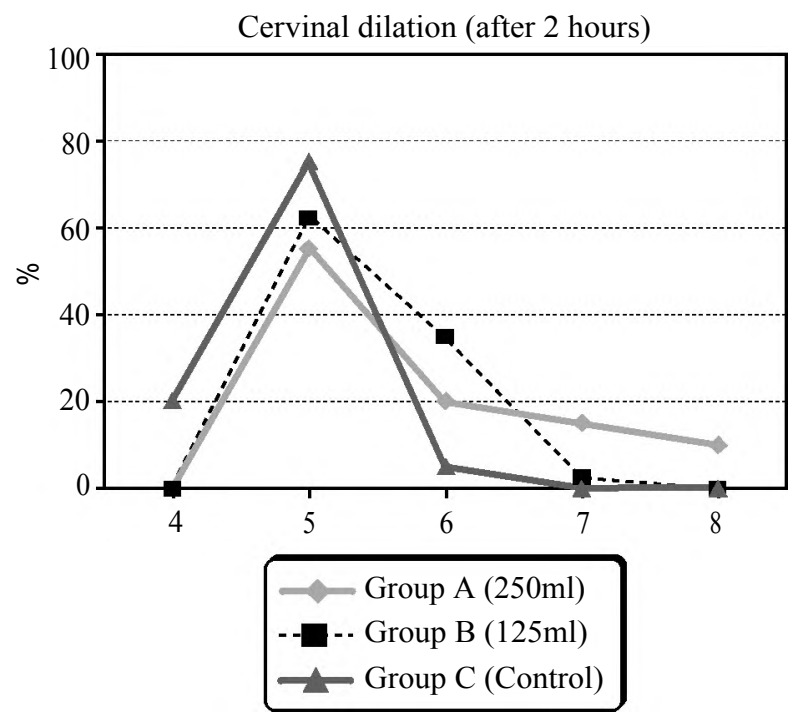

Fig. (4): Comparison between group A, group $B$ and group $C$ as regarding cervical dilation (after 2 hours).

Table (7): Comparison between uterine contraction after 2 hours, after 4 hours and after 6 hours in group A.

\begin{tabular}{cccccc}
\hline \multirow{3}{*}{ Group A } & $\begin{array}{r}\text { No of } \\
\text { uterine } \\
\text { contrac }\end{array}$ & $\begin{array}{c}\text { After } \\
\text { 2 hours }\end{array}$ & $\begin{array}{c}\text { After } \\
\text { 4 hours }\end{array}$ & $\begin{array}{c}\text { After } \\
\text { 6 hours }\end{array}$ & $\begin{array}{c}p \text { - } \\
\text { value }\end{array}$ \\
\hline - Uterine & 2 & $22(55)$ & $0(0)$ & $0(0)$ & $p=0.001 * *$ \\
contraction & 3 & $18(45)$ & $24(66.7)$ & $2(12.5)$ & \\
& 4 & $0(0)$ & $12(33.3)$ & $14(87.5)$ & $p=0.001 * *$ \\
\hline
\end{tabular}

p4: Comparison between uterine contraction after 2 hours and after 4 hours.

p5: Comparison between uterine contraction after 2 hours and after 6 hours.

Table (8): Comparison between uterine contraction after 2 hours, after 4 hours and after 6 hours in group B.

\begin{tabular}{|c|c|c|c|c|c|}
\hline Group B & & $\begin{array}{c}\text { After } \\
2 \text { hours } \\
\text { No. (\%) }\end{array}$ & $\begin{array}{c}\text { After } \\
4 \text { hours } \\
\text { No. }(\%)\end{array}$ & $\begin{array}{c}\text { After } \\
6 \text { hours } \\
\text { No. (\%) }\end{array}$ & $\begin{array}{c}p- \\
\text { value }\end{array}$ \\
\hline \multirow{3}{*}{$\begin{array}{l}\text { - Uterine } \\
\text { contraction }\end{array}$} & 2 & $22(55)$ & $\begin{array}{ll}0 & (0)\end{array}$ & $\begin{array}{ll}0 & (0)\end{array}$ & $p 4=0.001 * *$ \\
\hline & 3 & $18(45)$ & $25(64.1)$ & $5 \quad(25)$ & \\
\hline & 4 & $0(0)$ & $14(35.9)$ & $15(75)$ & $p 5=0.001 * *$ \\
\hline
\end{tabular}

Table (9): Comparison between duration of contraction after 2 hours, after 4 hours and after 6 hours in group A and group $\mathrm{B}$.

\begin{tabular}{|c|c|c|c|c|c|}
\hline $\begin{array}{l}\text { Duration of } \\
\text { contraction }\end{array}$ & $\begin{array}{c}\text { After } \\
2 \text { hours } \\
\text { Mean } \pm \text { SD }\end{array}$ & $\begin{array}{c}\text { After } \\
4 \text { hours } \\
\text { Mean } \pm \text { SD }\end{array}$ & $\begin{array}{c}\text { After } \\
6 \text { hours } \\
\text { Mean } \pm \text { SD }\end{array}$ & $\begin{array}{c}p \text { - } \\
\text { value }\end{array}$ & Sig. \\
\hline \multirow[t]{2}{*}{ Group A } & $37.9 \pm 3.1$ & $52.3 \pm 2.9$ & $57.4 \pm 2.8$ & $p 4=0.001 * *$ & HS \\
\hline & & & & $p 5=0.001 * *$ & HS \\
\hline \multirow[t]{2}{*}{ Group B } & $36.4 \pm 2.0$ & $44.2 \pm 5.2$ & $51.4 \pm 4.9$ & $p 4=0.001^{* *}$ & HS \\
\hline & & & & $p 5=0.001 * *$ & HS \\
\hline
\end{tabular}




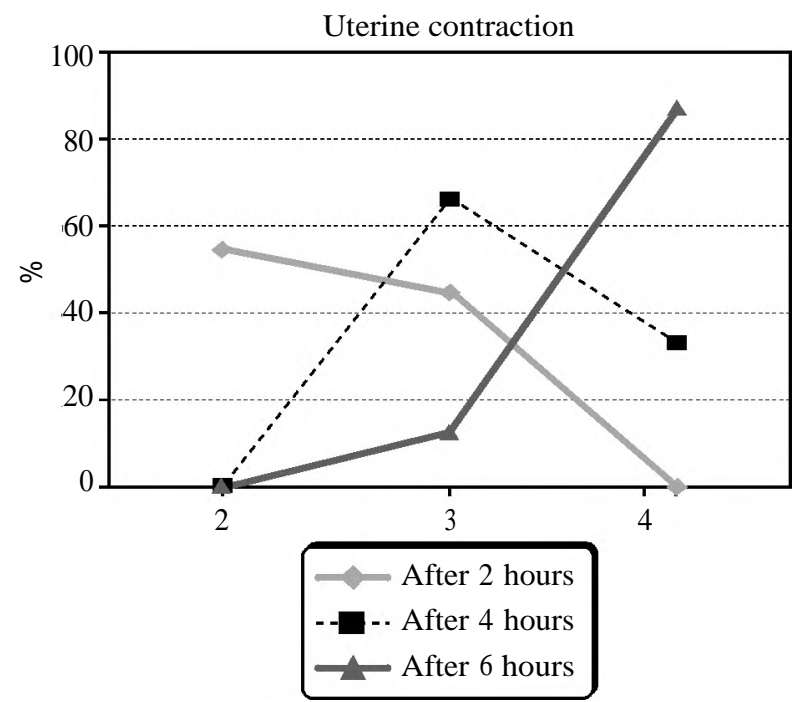

Fig. (5): Comparison between uterine contraction after 2 hours, after 4 hours and after 6 hours in group A.

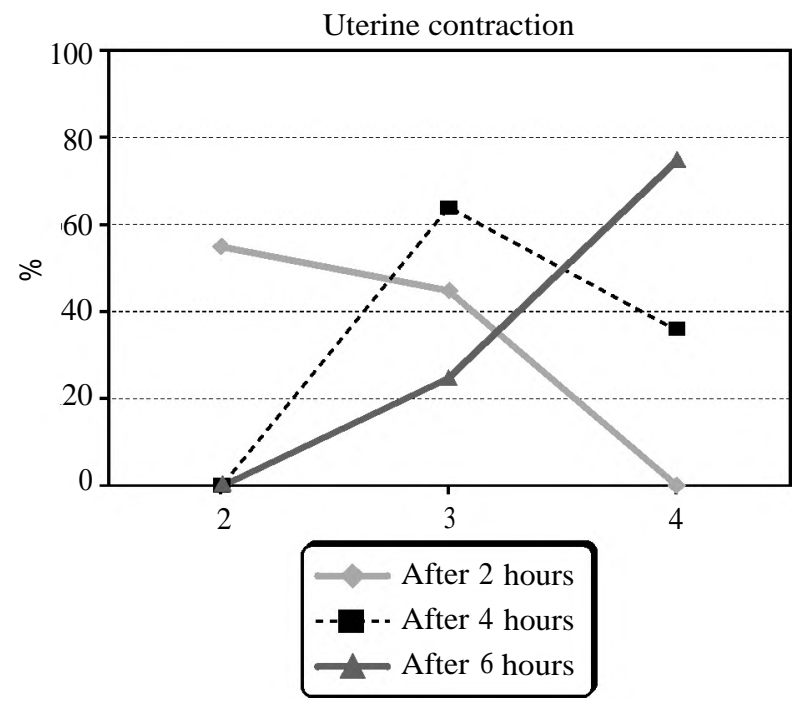

Fig. (6): Comparison between uterine contraction after 2 hours, after 4 hours and after 6 hours in group B.

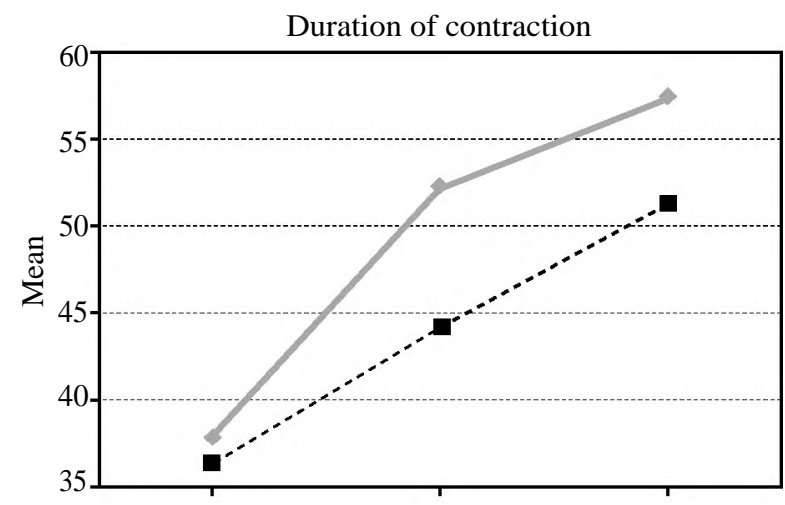

After 2 hours After 4 hours After 6 hours

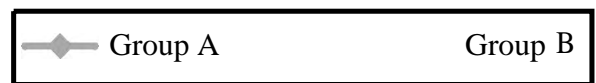

Fig. (7): Comparison between duration of contraction after 2 hours, after 4 hours and after 6 hours in group A and group B.

\section{Discussion}

In the start of the study there was non significant difference between the three groups as regards maternal age, uterine contractions, cervical dilatation or fetal head station.

There was a significant difference between the three groups when compared the progress of labour measuring the frequency and duration of uterine contractions as well as cervical dilatation and station of fetal head. We found that group A was preceding both groups B and group $\mathrm{C}$ in all these figures.

In our study, when comparing the three groups for the progress of labor by measuring frequency and duration of uterine contractions, cervical dilatation and station of fetal head, we found that all these measures were significantly higher in the $250 \mathrm{ml}$ group than in the $125 \mathrm{ml}$ group and the control group. These results agree with the study performed by (Gaby and Alan, 2001) [8] who studied the effect of fluid on labor and found that $125 \mathrm{ml}$ intravenous fluid per hour to laboring patients may be insufficient for optimal labor performance. (Huddleston et al., 2003) [9] reported that a rapid expansion of the maternal vascular volume by 500 to $1000 \mathrm{ml}$ of intravenous fluid probably augments cardiac output and uterine blood flow. In addition, volume expansion might depress the release of oxytocin from the posterior pituitary and thus uterine contractility decrease. In the present study, infusing Ringer lactate solution significantly reduced the mean duration of active labor.

This is in agreement with [2] (Garite etal .,2000) who reported that in a study with 195 nulliparous women performed in California,

USA, the frequency of prolonged labor was less among women who received $250 \mathrm{~mL}$ per hour than among others who received $125 \mathrm{~mL}$ per hour. (Eslamian et al., 2006) [3] reported a significantly shorter duration of labor in a group that received $250 \mathrm{~mL}$ per hour than in another that received $125 \mathrm{~mL}$ per hour (253 minutes vs. 386 minutes), this is in agreement with our study. (Maderia et al., 2007) [10] reported that the mean duration of labour was significantly reduced (by approximately one and half hours) in the group that received the increased rate of $250 \mathrm{~mL} /$ hour of fluid. (Coco et al. 2010) [11] randomized 80 women to receive IV fluids at $250 \mathrm{~mL}$ per hour or no IV fluids. Women in both groups were allowed to drink as much fluids as they desired (water, juice). There were no differences between groups with regard to total 
labor length, this is in contrast with our study. Kavitha et al., [12] reported that the mean labor duration was 48 minutes shorter for 98 women who received a Ringer lactate infusion at a rate of $250 \mathrm{~mL}$ per hour than for 96 women who were given fluids to drink, this is in agreement with our study.

Moghadam et al., [13] reported that the duration of the 2 nd stage of labour were reduced for women receiving intravenous fluids.

Labor is augmented by intravenous infusion of oxytocin when inadequate uterine contractions prolong labor. In this study there was no significant difference in frequency of oxytocin administration for inadequate labor progress between the three groups. This is in agreement with Kavitha et al., [12] who reported that the need for oxytocin augmentation was similar in all groups. Our results in contrast with Garite et al., [2] who reported that there was a trend toward a lower frequency of oxytocin administration for inadequate labor progress in the $250 \mathrm{ml}$ group. Morris, [14] reported that, increased intravenous fluid during labor reduced the need for oxytocin.

Gaby and Alan, [8] who studied effect of fluid on labor and they found that the amount of maternal hydration during labor lowered frequency of oxytocin administration for inadequate progress of labor.

Eslamian et al., [3] mentioned that the frequency of oxytocin administration was significantly lower ( $p=0.001)$ in the $250 \mathrm{ml}$ group than in the $125 \mathrm{ml}$ group.

In our study, there was no significant difference between the three groups in the frequency of cesarean section. This result agrees with Garite et al., [2] .

Shrivastava et al., [15] reported that there was no difference in the rates of caesarean section between the two groups.

Kavitha et al., [12] who reported that no significant difference in the frequency of cesarean deliveries between groups. Moghadam, [13] reported that There was no statistically significant reduction in the number of Caesarean Sections (CS) between groups.

Our result in contrast with Eslamian et al., [3] who reported that there was statistically lower frequency of cesarean deliveries $(p=0.1)$ in the
$250 \mathrm{ml}$ group than in $125 \mathrm{ml}$ group. In our study there were no infants with a low Apgar score at five minutes in either group as shown in (Table 4) this is in agreement with Moghadam et al., [13] Kavitha et al., [12] reported that there was no evidence of a statistically significant difference in admission to the neonatal unit.

\section{References}

1- American College of Obstetrics and Gynecology Committee on Practice Bulletins-Obstetrics. ACOG Practice Bulletin Number 49, December 2003: Dystocia and augmentation of labor. Obstet. Gynecol., 102 (6): 1445-54, 2003.

2- GARITE T.J., WEEKS J., PETERS-PHAIR K., PATTILLO C. and BREWSTER W.R.: A randomized controlled trial of the effect of increased intravenous hydration on the course of the course of labor in nulliparous women. Am. J. Obstet. Gynecol., 183 (6): 1544-8, 2000.

3- ESLAMIAN L., MARSOOSI V. and PAKNEEYAT Y.: Increased intravenous fluid intake and the course of labor in nulliparous women. Int. J. Gynecol. Obstet., 93 (2): 102-5, 2006.

4- CHENG Y.W., DELANEY S.S., HOPKINS L.M. and CAUGHEY A.B.: The association between the length of first stage of labor, mode of delivery, and perinatal outcomes in women undergoing induction of labor. Am. J. Obstet. Gynecol., 201 (5): 477.e1-7, 2009.

5- HANDA V.L. and LAROS R.K.: Active-phase arrest in labor: Predictors of cesarean delivery in a nulliparous population. Obstet. Gynaecol., 81: 758-63, 1993.

6- MAUGHAN R.J. and NOAKES T.D.: Fluid replacement and exercise stress: Abrief review of studies on fluid replacement and some guidelines for the athlete. Sport Med., 12 (1): 16-31, 1993.

7- CUNNIGHAM F.G., LARRY C., KATHARINE D., LEVENO K.L. and BLOOM S.L.: Normal labor and delivery. In: Williams' Obstetrics. Chapter 17; 22 nd ed 2005. Appleton and Lang, New York, p. 420, 427, 439.

8- GABY and ALAN R.: Hydration improves the course of labor. Townsend letter for doctors and patients. April 1, 2001.

9- HUDDLESTON J.F., LUIS SANCHEZ-RAMOS and HUDDLESTON K.W.: Acute management of preterm labor. In: Clinics in Perinatology. Copyright WB Saunders Company, 30: 4, 2003.

10- MADERIA L.M., HOFFMAN M.K., WILSON S. and CHICHESTER M.L.: Effect of intravenous hydration on labor length and delivery mode [abstract]. Obstetrics \& Gynecology, 109 (4 Suppl): 90S, 2007.

11- COCO A., A. DERKSEN-SCHROCK, et al.: "A randomized trial of increased intravenous hydration in labor when oral fluid is unrestricted." Fam. Med., 42 (1): 526, 2010 . 
12- KAVITHA A., K.P. CHACKO, et al.: "A randomized controlled trial to study the effect of IV hydration on the duration of labor in nulliparous women." Arch. Gynecol. Obstet., 285 (2): 343-6, 2012.

13- MOGHADAM A. and REZAEIAN M.: Increased intravenous hydration of nulliparas in labor. International Journal of Gynecology and Obstetrics, 118 (3): 213-5, 2012.
14- MORRIS J.: Evidence-based Obstetric and Gynecology, Mar., Volume 4 Pages 15-16, 2002.

15- SHRIVASTAVA V.K., GARITE T.J., JENKINS S.M., SAUL L., RUMNEY P., PRESLICKA C., et al.: A randomized, double-blinded, controlled trial comparing parenteral normal saline with and without dextrose on the course of labor in nulliparas. American Journal of Obstetrics and Gynecology, 200 (4): 379.e1-6, 2009.

\section{العلاقة بين المحاليل الوريدية ومعدل تقدم الولادة الودة

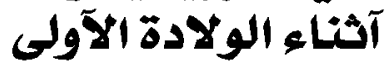

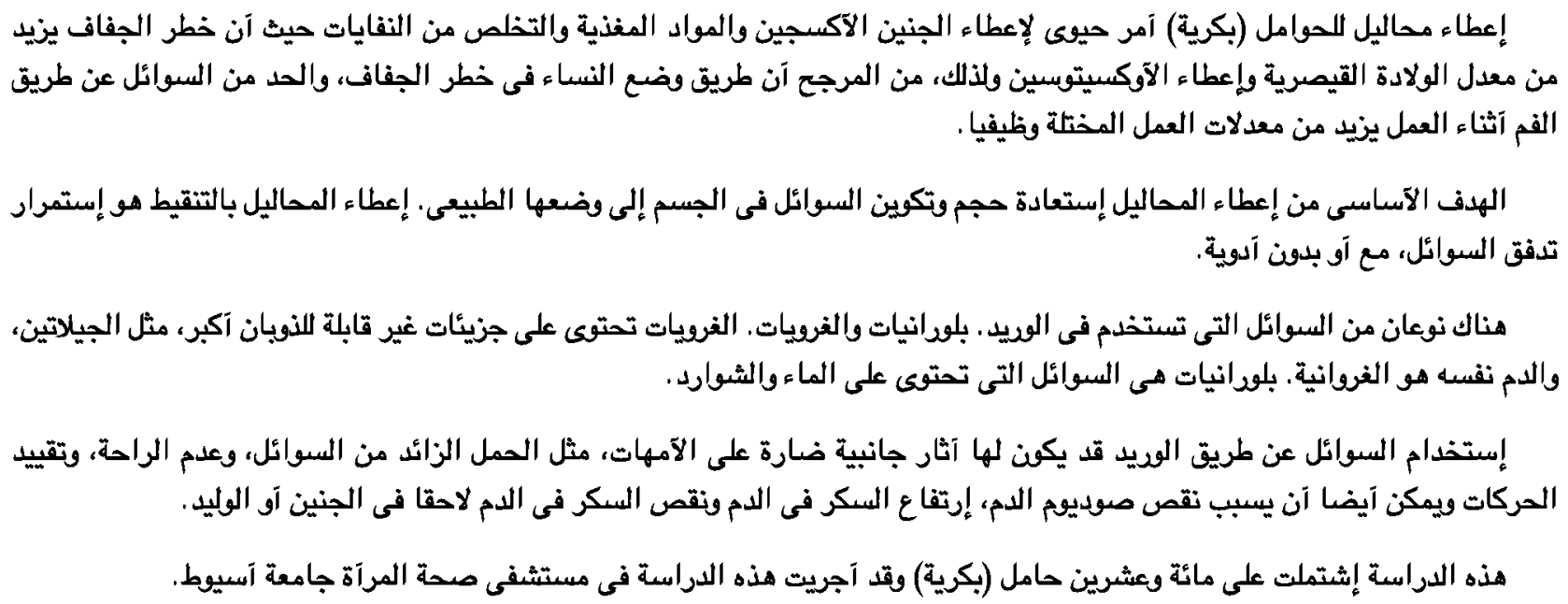

